\title{
Research on the Construction of Simulation Training Platform for Warehousing and Distribution*
}

\author{
Shijun Yuan \\ Hunan Vocational College of Modern Logistics \\ Changsha, China 410131
}

\author{
Jianhua Chen** \\ Hunan Vocational College of Modern Logistics \\ Changsha, China 410131 \\ **Corresponding Author
}

\begin{abstract}
This paper studies the construction of the simulation training platform for warehousing and distribution management in order to promote the teaching of the core curriculum of the major from the aspects of the definition, the research review, the theoretical basis, the construction target, the construction characteristics and the content.
\end{abstract}

Keywords—warehousing and distribution; simulation training; research

\section{INTRODUCTION}

As a very important core course in the course system of logistics management, storage and distribution management is a very important core course. The quality of teaching directly affects the professional quality of the students majoring in logistics management. Therefore, it is urgent to explore an effective teaching method to improve the teaching quality of the course of storage and distribution management. The construction of simulation training platform for warehousing and distribution management will greatly promote the core curriculum teaching.

\section{THE DEFINITION OF THE SUBJECT}

According to the work flow of warehousing and distribution, simulation technology is used to simulate the whole process. The simulation training system of warehousing and distribution will be promoted in a comprehensive and well-organized way, so as to ensure the effectiveness of the simulation training.

\section{RESEARCH OVERVIEW}

Simulation and modeling refer to the complex activities of constructing the model of real system in real world and carrying out simulation on the computer. It mainly includes three basic parts, the real system, model and computer, and considers the relationship among the three basic parts. These are the modeling relationship and the simulation relationship. The simulation system can be applied to the development department of aviation, space and various weapon systems, power, transportation, communications, chemical and nuclear energy fields, system concept research, system feasibility study, system analysis and design, system development, system

*Stage Results of Hunan Vocational College of Modern Logistics (College project: JY201113).). testing and evaluation, system operator training and system prediction, the use and maintenance of the system and other fields. With the development of simulation technology, the application purpose of simulation technology tends to be diversified and comprehensive. In the past 20 years, with the rapid development of system engineering and science, the simulation technology has been extended from the traditional engineering field to the non-engineering field. So, it has also been widely used in the social and economic system, the environment ecosystem, the energy system, the biomedical system and the education and training system.

Flexsim is used at the logistics simulation training of undergraduate and graduate. It is a powerful analytical tool that helps engineers and designers make correct decisions in the design and operation of the system. But it requires high quality of training personnel. So, this kind of simulation training is not very practical for vocational students of logistics management. Therefore, it is urgent to have a simulation training tool or platform for vocational education of higher vocational logistics to enhance the level of practical training teaching.

\section{THEORETICAL BASIS}

The theoretical basis for the construction of the simulation training platform for warehousing and distribution is warehousing and distribution work flow.

\section{A. Warehousing Management}

Storage management refers to the planning, organization, control and coordination of storage units, which include storage space management, goods management, personnel labor, management decision-making and a series of management work.

The main tasks of warehousing management are the following:

(1) With the principle of achieving the ultimate goal of warehousing management, establish management organization and warehousing organization and establish a staff team with simple management structure and a clear division of labor. Generally, there are internal administrative management, equipment management, financial management, safety management, operation management of storage and other necessary departments. 
(2) Organize warehousing operations on the principle of high efficiency and low cost

Warehousing operations should make full use of warehousing equipment, advanced warehousing technology and effective management tools to reduce costs and maintain continuous and stable storage operations. Its specific scope includes warehousing of goods, acceptance, maintenance and custody, quality maintenance, safety protection, tally and handing over, ex-warehousing and other operations.

(3) Obtain the optimal allocation of storage resources by means of market economy

Warehousing management needs to take advantage of its own advantages in the market to absorb the input of resources in order to maximize the benefits. The specific tasks include determining the construction of warehousing according to the market supply and demand, selecting the storage address reasonably, determining the storage function and the configuration of the facilities, and optimizing the layout of the storage.

\section{B. Distribution Management}

Distribution is actually a collection and distribution process of goods, which includes three steps: collection, classification and distribution. These three steps consist of a series of distribution operations, which are usually referred to as distribution elements. The basic elements of distribution include collection of goods, sorting, allocation of goods, stowage, distribution and transportation, delivery service, and distribution processing.

- Collection of goods: It is the most important part of distribution. Collect decentralized and deliverable goods for sorting and distribution. Sometimes it is necessary to concentrate the goods from several or even dozens of suppliers to one place.

- Sorting: It is to sort out deliverable goods from storage position, equip them completely, classify the goods according to requirements of stowage and delivery, and send them to the designated place.

- Allocation of goods: It is to put the classified goods passing the inspection of allocation into containers and mark them, then send to the delivery area, and deliver it after loading.

- Stowage: It requires to make full use of the load and volume of transport tools (such as wagons, ships, etc.), use advanced loading methods to reasonably arrange the loading of goods.

- Distribution and transportation: Distribution and transportation belong to terminal transportation and branch line transportation. It has a shorter distance, smaller scale and higher frequency than the general transport form, and generally uses automobile as a means of transportation. The route selection issues of distribution and transportation involved generally don't exist in trunk transportation. In trunk transportation, trunk line is the only transportation route. Because of many customers and locations, distribution and transportation generally are concentrated in the city or the suburbs, and the traffic is more complex. There is space and time peak and valley alternation. It becomes the difficulty in distribution and transportation to effectively match loading and route selection.

- Delivery service: Fully transfer goods to customers, effectively and conveniently handle relevant procedures and complete settlement. The unloading place and the way of unloading should be also considered.

- Distribution processing: It is a circulation processing which is made according to requirements of customers.

\section{CONSTRUCtion GOALS}

Through the simulation training of the simulation training platform for warehousing and distribution, students can master the knowledge of warehousing and distribution, train abilities and train qualities. In general, they are:

\section{A. Ability Goals}

- Having super practical ability and familiar with the operation of 3D warehousing and distribution simulation training software

- Having professional logistics management capability, effectively organizing various logistics activities and formulating logistics work plan

- Having the basic abilities to manage and operate various modern advanced logistics technologies and analyze specific problems

- Be familiar with the work flow of software and the production of relevant documents

- Be able to calculate the cost of warehousing

\section{B. Knowledge Goals}

- The concept and function of warehousing; the task of warehousing; the status of warehousing in logistics management

- Warehouse function and classification; warehouse structure and layout; warehouse equipment;

- Warehousing, management in warehouse, exwarehouse, distribution and loading operations

- The concept and function of distribution

- The function of distribution center; the basic operations of distribution center.

- The process of sorting and shipment

- Distribution route design

C. Quality Goals

- Basic qualities in communication with customers 
- Basic qualities in language and writing expression

- Having a sense of team cooperation

- Good professionalism

- Having a sense of cost and a sense of competition

- The quality of the application of modern information technology

- Basic qualities of self-study, judgment and creative thinking

- $\quad$ Ability to solve problems

\section{CHARACTERISTICS AND CONTENTS OF THE PROJECT CONSTRUCTION}

The simulation training platform for warehousing and distribution is developed on the basis of 3D practical teaching model which has referred to the educational concept of "combining work with learning" and has made a new attempt on the assessment of the students: replacing "the assessment of knowledge structure" with "the assessment of the ability standard". After several rounds of common analysis and discussion with relevant warehousing and distribution enterprises and experts, a new system of assessment and teaching is established. It includes post requirements $\rightarrow$ competency standards $\rightarrow$ training target $\rightarrow$ curriculum system $\rightarrow$ professional skills $\rightarrow$ post application $\rightarrow$ post requirements. Such a cycle will enable students to focus on the core of competency standards and post requirements.

This training method is mainly presented at the followings:

(1) The training environment is real, and the logistics elements are complete: providing the real operating environment of various logistics enterprises in reality, integrating knowledge and interest, so that students can learn knowledge and skills in an easy operation liking playing games.

(2) Subverting the tradition and changing the role of teachers and students; students plan for themselves and complete tasks dominantly. Teachers guide, assist and assess the implementation process and result. It can improve the enthusiasm and initiative of students to participate.

(3) The content of learning is work; use task driven, process simulation, clear the job responsibilities, change practice after learning into learning by doing, so that students learn through work. It can improve their practical skills fast.

(4) To assess the implementation of each task, strengthen the process monitoring in teaching, and truly achieve the purpose of assessment. 


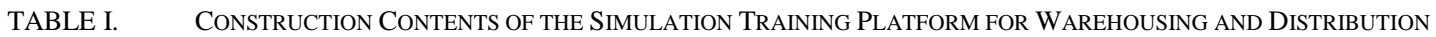

\begin{tabular}{|c|c|}
\hline & equirements for the operation of simulation training \\
\hline $\begin{array}{l}\text { Contract } \\
\text { business }\end{array}$ & $\begin{array}{l}\text { Aderstand the process of customer development and the methods for customer development, be able to connect with storage customers and } \\
\text { mmunicate with them } \\
\text { arn to make sales plans } \\
\text { oficient in writing warehouse contracts, familiar with the process of contract signing, and familiar with the terms and forms of contracts to } \\
\text { signed }\end{array}$ \\
\hline $\begin{array}{l}\text { Dealing with } \\
\text { complaint of } \\
\text { customers }\end{array}$ & $\begin{array}{l}\text { mely handle customer complaints and formulate reasonable solutions } \\
\text { aster the principles, techniques and effective methods of complaint handling }\end{array}$ \\
\hline $\begin{array}{l}\text { Warehousing } \\
\text { process }- \\
\text { pallet shelf } \\
\text { area }\end{array}$ & $\begin{array}{l}\text { 1) Through this practical training, students can accurately describe the warehousing process in warehouse management, identify and analyze } \\
\text { various factors influencing warehousing operations, and deal with and utilize the factors influencing warehousing operations. } \\
\text { Repeat the supplier's delivery method } \\
\text { 2) Skilled in receiving, inspecting and warehousing goods, and able to independently make warehousing vouchers for goods } \\
\text { 3) Put goods of different characteristics onto suitable pallet shelf area and know the differences if they are placed in other shelf area } \\
\text { 4) Master the accounting method of warehousing cost, summarize according to the accounting form of warehousing cost, and reduce the } \\
\text { warehousing cost }\end{array}$ \\
\hline $\begin{array}{l}\text { Warehousing } \\
\text { process- e- } \\
\text { tag area }\end{array}$ & $\begin{array}{l}\text { 1) Able to independently produce warehousing vouchers for goods } \\
\text { 2) Skilled in receiving, inspecting and warehousing goods } \\
\text { 3) Put goods of different characteristics onto suitable pallet shelf area and know the differences if they are placed in other shelf area } \\
\text { 4) Master the accounting method of warehousing cost, summarize according to the accounting form of warehousing cost, and reduce the } \\
\text { warehousing cost }\end{array}$ \\
\hline $\begin{array}{l}\text { Warehousing } \\
\text { process } \\
\text { light } \quad \text { shelf } \\
\text { area }\end{array}$ & $\begin{array}{l}\text { 1) Able to independently produce warehousing vouchers for goods } \\
\text { 2) Skilled in receiving, inspecting and warehousing goods } \\
\text { 3) Put goods of different characteristics onto suitable pallet shelf area and know the differences if they are placed in other shelf area } \\
\text { 4) Master the accounting method of warehousing cost, summarize according to the accounting form of warehousing cost, and reduce the } \\
\text { warehousing cost }\end{array}$ \\
\hline $\begin{array}{l}\text { Warehousing } \\
\text { process } \\
\text { automatic } \\
\text { stereoscopic } \\
\text { storage area }\end{array}$ & $\begin{array}{l}\text { 1) Able to independently produce warehousing vouchers for goods } \\
\text { 2) Skilled in receiving, inspecting and warehousing goods } \\
\text { 3) Master the precautions and methods for automatic warehousing } \\
\text { 4) Understand the reason why this batch of goods is put into the automatic stereoscopic storage area } \\
\text { 5) Master the accounting method of warehousing cost, summarize according to the accounting form of warehousing cost, and reduce the } \\
\text { warehousing cost }\end{array}$ \\
\hline $\begin{array}{l}\text { Warehousing } \\
\text { process - loft } \\
\text { shelf area }\end{array}$ & $\begin{array}{l}\text { ndently produce warehousing vouchers for goods } \\
\text { ving, inspecting and warehousing goods } \\
\text { reason why the goods were put into the loft shelf area } \\
\text { counting method of warehousing cost, summarize according to the accounting form of warehousing cost, and reduce the }\end{array}$ \\
\hline $\begin{array}{l}\text { Warehousing } \\
\text { process - } \\
\text { goods } \\
\text { warehousing }\end{array}$ & $\begin{array}{l}\text { 1) Able to independently produce warehousing vouchers for goods } \\
\text { 2) Skilled in receiving, inspecting and warehousing goods } \\
\text { 3) Master the accounting method of warehousing cost, summarize according to the accounting form of warehousing cost, and reduce the } \\
\text { warehousing cost }\end{array}$ \\
\hline $\begin{array}{l}\text { Management } \\
\text { in warehouse }\end{array}$ & $\begin{array}{l}\text { Be able to independently make the transferring order of goods } \\
\text { Master the procedure and method of allocating and storing warehousing } \\
\text { Master the accounting method of warehousing cost, summarize according to the accounting form of warehousing cost, and reduce the cost of } \\
\text { warehousing } \\
\text { Be familiar with the meaning, purpose and content of the inventory operation, and master the procedures of the inventory operation, which } \\
\text { will effectively prepare for inventory before the inventory, and effectively clean the inventory site as required } \\
\text { Understand the reading and use of various inventory forms, accurately calculate the profit and loss differences, reasonably analyze the } \\
\text { inventory results, and correctly handle the profit and loss of the inventory } \\
\text { Establish a sense of responsibility, understand the importance and responsibility of inventory operation, and master the principles of } \\
\text { inventory profit and loss management }\end{array}$ \\
\hline $\begin{array}{l}\text { Delivery to } \\
\text { supermarket }\end{array}$ & $\begin{array}{l}\text { 1) Be able to independently make delivery vouchers of goods } \\
\text { 2) Skilled in the delivery of goods } \\
\text { 3) Understand the purpose of the delivery operation and master the delivery process } \\
\text { 4) Master the method of cost accounting for warehouse delivery and distribution, and consider how to optimize the route and reduce the } \\
\text { corresponding costs } \\
\text { 5) Point out the main manifestations of unreasonable distribution, the judgment standards of reasonable distribution and the methods adopted } \\
\text { for reasonable distribution }\end{array}$ \\
\hline $\begin{array}{l}\text { Delivery } \\
\text { stores }\end{array}$ & $\begin{array}{l}\text { 1) Be able to independently make delivery vouchers of goods } \\
\text { 2) Skilled in the delivery of goods } \\
\text { 3) Understand the purpose of the delivery operation and master the delivery process } \\
\text { 4) Master the method of cost accounting for warehouse delivery and distribution, and consider how to optimize the route and reduce the } \\
\text { corresponding costs } \\
\text { 5) Point out the main manifestations of unreasonable distribution, the judgment standards of reasonable distribution and the methods adopted } \\
\text { for reasonable distribution }\end{array}$ \\
\hline
\end{tabular}




\section{CONCLUSION}

Simulation Training Platform for Warehousing and Distribution is an interactive platform whose overall structure is designed on the basis of the overall logistics business process and the posts, the responsibilities and tasks of posts involved in the whole logistics process. It can provide a platform for teachers and students and employees to engage in the learning and testing of logistics knowledge, skills, laws and regulations. It also organically combines with the public information platform of Hunan Logistics. It is a comprehensive platform for personnel training, staff training, and talent management and student employment.

Simulation Training Platform for Warehousing and Distribution fully embodies the essence of modern logistics, with characteristics of novelty, simulation, interaction, ease of use, real-time, and generalizability. It integrates knowledge, interestingness, operability, interaction and visualization. It is not only a $3 \mathrm{D}$ animation game, but also 3D animation simulation for logistics equipment, information process, key business, key operation, key knowledge points and professional accomplishment training.

\section{REFERENCES}

[1] Sun Wenjun. Comprehensive Training and Development of Warehousing and Distribution Practice. Chinese Market, 28th Issue in 2016.

[2] Li Hua. Project-based Curriculum Reform and Practice of Warehousing and Distribution. China's Off-campus Education, 2013 (09).

[3] Li Zhengkai. Training and Teaching Design of Warehousing and Distribution Management Course based on Post Capacity Training. Article Collection of Science and Education (for Midmonth), (2015) (04). 